\title{
VALUE STREAM ANALYSIS OF VEGETABLE SUPPLY CHAIN IN BANGLADESH: A CASE STUDY
}

\author{
Rubayet Karim $^{1}$ and Jony Biswas ${ }^{2}$ \\ ${ }^{1}$ Dept. of Industrial \& Production Engineering, Jessore University of Science and Technology \\ ,Jessore, Bangladesh \\ ${ }^{2}$ Dept. of Industrial \& Production Engineering, Jessore University of Science and Technology \\ ,Jessore,Bangladesh
}

\section{ABSTRACT}

Bangladesh is primarily an agricultural country. Agriculture plays a vital role in its economy in terms of food safety, value addition, export earnings and employment. Bangladesh weather and soils are suitable for a variety of harvests cultivation. More than 100 vegetables are produced in this country. Various types of vegetables are grown in rural Bangladesh in small homesteads and large agricultural land both for the own consumption and commercial purpose. Commercial vegetable trading has an integrated supply chain system which depends on some intermediaries and their activities to take the vegetables from producers to consumers. The main problem is consumer pays two to three times more than the producers' margin. The main objectives of this paper are to investigate the existing vegetable supply chain through value stream analysis and to identify different stakeholders and their activities, and also to illustrate various cost and price movement towards different stages of the supply chain. Based on the questionnaire different data are collected from farmers, different market actors, and consumer and finally problems regarding vegetable value chain are identified. In the existing situation, producers have no control over the vegetable supply chain, product pricing; rather they are strongly influenced by market syndicates. In order to make the problems of the existing supply chain network more understandable different analysis is conducted in this paper. Finally a new network is proposed to the vegetable supply chain.

\section{KEYWORDS:}

Vegetable Supply chain; Value Stream Analysis; Future Value Chain; Cost and Price Movement

\section{INTRODUCTION}

The value chain is a key framework for understanding how a product moves from producer to the customer. Value analysis is a full range of activities which are required to bring a product to service from conception through different phases of production involving a combination of physical transformation and the input of various producer services, delivery to final consumers and final disposal are used. Value chain analysis provides a way to understand the business policy, mechanism, and product and information movement for increasing efficiency, productivity, customer service and a better business environment. It initiates better linkage among the producer, market actors, and consumer in the supply chain. Michael Porter developed value chain concept, separates value adding activities from

DOI: $10.5121 /$ ijmvsc. 2016.7205 
non-value adding, wasteful activities and initiate strategies to minimize non-value adding activities. As a result value adding activities provides the company many advantages such as, lower manufacturing cost, minimize waste, higher profit margin, reduce defects and rework, ensure quality, achieve a better brand image, quick response to market etc.

This paper mainly focuses a vegetable supply chain network from Jessore to Dhaka and the other divisional market of Bangladesh. Jessore, Kustia, Jhinaidah,Magura, Satkhira, Cuyadanga, Comilla, Bogra, Rajshahi all are famous for their fresh quality green vegetables. In the year 2015, about 14105 hector land cultivates only for vegetable in Jessore area. (Source: Division of Agriculture Extend, Jessore). In the Jessore vast amount of vegetable produce, so that Farmer can provide vegetable for another district. In the supply chain of vegetable trading, different intermediary stakeholder is involved between producer and consumer. They are the local wholesaler, divisional wholesaler, the regional wholesaler, and retailer. These intermediary stakeholders create a long supply chain. Intermediaries are an essential part of a vegetable supply chain in Bangladesh. They share profit with the producer without adding any value to the product. Their main function is transporting vegetables and keeps business communication with other market actors. At present, farmers have no influence in product pricing rather they are strongly managed and monopolized by giant traders, wholesalers, and retailer syndicate and they take the profitability and preference of farmers. But farmers in Bangladesh cannot avoid intermediaries' for shifting their product to market [2]. As a result, the consumer doesn't get the product at an affordable price. The consumer pays two to three times more than the farmer's price. This paper tries to show and explain the vegetable supply chain by conducting value stream analysis, cost and profit flow analysis and cause- effect analysis to identify non-value adding activities and the causes of the price hike. Besides this, it's recommended some appropriate policy and design a future value chain to overcome these barriers and constraint of the present supply chain. So, that the farmer and the consumer both are benefited. Value and chain are two key concepts of the study of value chain analysis. Value means value added in the value stream analysis, as it characterizes the incremental value of a final product from the processing of a product. For agro products' value addition can be express as production, food safety, and food quality. The price of the product shows its incremental value. Chain refers to the process and stakeholder involve in the cycle of a product [3].Value chain analysis is a strategic tool used to analyze internal activities of a process. The true goal of VCA is to identify which activities are most valuable and which need to improve, need to minimize to provide competitive advantages. The study of value chains comprises of two key concepts: value and chain. The term value is synonymous to "value added" in the Value Chain Analysis (VCA) as it characterizes the incremental value of a resultant product produced from the processing of a product. Kaplinsky and Morris [4] define VCA as "study of the full range of activities which are required to bring a product or service from conception, through the different phases of production (involving a combination of physical transformation and the input of various producer services), delivery to final consumers, and final disposal after use". Sanogo [5] explains the movement of a product from one stage to another and identification of the actors, firms and their services, also adds an analysis of the institutional support to production at various stages to VCA. Hence, food VCA (FVCA) stands on the pillars of production, processing and marketing of food products.Lusine et al. [6] presented performance measures to assess the success of supply chains. The authors used four criteria, including efficiency, flexibility, responsiveness, and food quality to assess the performance of value chains. Efficiency points to the utilization of resources in the supply chain and its measures include production costs, profit, return on investment and inventory. Flexibility indicates the degree of responsiveness of the supply chain to a changing 
environment and is measured through customer satisfaction, volume flexibility, delivery flexibility, and lost sales. Responsiveness shows the time spent in the fulfillment of a request and is measured through fill rate, product lateness, customer response time, lead-time, shipping errors, and customer complaints.

Food quality, the fourth and final criteria of performance measure, is further divided into product and process quality. Product quality consists of product safety and health, sensory properties, shelf-life, and product reliability and convenience while process quality consists of the characteristics of production and marketing systems. Taylor [7] suggested the following five principles for consideration while conducting value chain studies:

i. Identify what creates value from the end-user perspective and not from the individual firm's perspective.

ii. Find out the steps across the value stream. In addition, highlight waste created at each step.

iii. Implement the actions that create value and flow of the product without interruption, diversions or waiting.

iv. Based the output produced on customer demand.

v. Continuously remove successive layers of waste in both the product and the processes.

Sanogo [5] added to Taylor's [7] list of best practices. In Sanogo's [5] view, VCA should consider:

vi. Systematically mapping the actors taking part in the production, distribution, marketing, and sales of a product.

vii. Identifying and estimating the share of the costs and benefits of each actor in the chain

viii. Determining the scope for quality enhancement within the chain. Quality enhancement may involve improvements in the production, delivery, and processing of the product, its packaging and design.

ix. Highlighting the role of governance in the chain

\section{SIGNIFICANCE OF THE RESEARCH}

Jessore has a great opportunity to become one of the prevalent green vegetable producer in Bangladesh and abroad because here grows a lot of green vegetables by efficient farmers, fertile land, and better weather. But certain problems may exist in this vegetable value chain such as numerous stakeholders like farmers, small and medium wholesalers, transporters, retailers and end customers, poor packaging and poor handling methods and marketing system causes high post-harvest loss of the commodity, high transportation cost, price hike, etc. Farmer lack of knowledge on food supply chain, vegetable marketing management, lack of linkage with regional market, consequently reduces farmers' income. On the other hand, in Bangladesh it has been found that the intermediaries in the market are small in number but they are organized. So they dominate farmer and compel them to sell produce at a lower price as the farmer has no way to bring back the product from the market as it involves extra cost. One of the main reasons for not getting the best price is the involvement of local broker and wholesaler organization's dominance. But there are selected financial difficulties and avoidable activities which increase the ultimate product price. Analyzing value chain tries to identify the market problem, the causes of cost increases, Intermediaries, and their activities. By reducing the redundant activities, it is possible to improve the vegetable supply chain. It reduces the unwanted cost and also creates a large 
market of vegetable for both home and abroad. Consequently, a farmer can get the maximum value of their product and customer can consume at the lowest cost as possible.

\section{Methodology}

This paper is based on the value chain approach, focusing on intermediary's activities and cost flow. This case study is conducted in Jessore towards Dhaka for the vegetable supply chain. The value chain study follows both quantitative and qualitative methods for data collection. However, the process is fully participatory through ensuring maximum involvement of farmers, wholesalers, supply chain intermediaries, retailer, and customer. However,the research paper considered a mix of the in-depth interview, focus group discussion, projective technique, and observation technique. The necessary steps required to perform the case study are presented below.

\subsection{Primary investigation}

Considering the availability and huge production of vegetable in Jessore, Jessore district is selected as the study area. Primarily vegetable supply chain from Jessore towards Dhaka is set as an investigation chain in order to develop a general understanding the opportunities on the research objectives.

\subsection{Literature review}

To gain sufficient knowledge on value chain analysis and vegetable supply chain analysis,few books, articles, research paper and project report are collected and studied.

\subsection{Preparing primary questionnaire}

After a primary investigation and literature review, a set of a primary questionnaire is prepared for farmers, wholesaler, market intermediaries, retailer, and customer. Primary tools and techniques for analysis are also selected.

\subsection{Investigation through the literature}

A field visit is conducted after preparing the primary questionnaire, and this questionnaire is based on value chain analysis technique and research objectives.

\subsection{Preparing final questionnaire}

The final questionnaire is prepared after an investigation. During this phase, the final tools for field investigation and interview with the key informants and market actors are designed. Final questionnaire, tools, and technique are then used for the study and analysis.

\subsection{Data collection}

Finally, data are collected through observation and questionnaire. Data are collected from both primary and secondary sources. Primary data are collected directly from an interview and group discussion of respondents. Secondary data are collected from Bureau of statistics (BBS), Agricultural Ministry of Bangladesh, Agricultural Extend Department, Hortex NGO, Newspaper and internet files 


\subsection{Data processing and analysis}

The informational data collected are sorted and arranged so that further study and analysis could be performed. Quantitative data are arranged by using graphs and tables. Various types of information are given as a profile. Dataare analyzed by using pie charts, cause- effect analysis, flow charts, process tree, etc. The data that have been obtained by interview, questionnaire, and observation are structured in an order. After completion of the data processing, the analysis has been performed. The analysis process of the vegetable value chain is shown in figure 1.

\subsection{Result and Discussion}

Finally results from the overall analysis are given and the necessary guideline is provided for the improvement of the supply chain to overcome problems of the present supply chain.

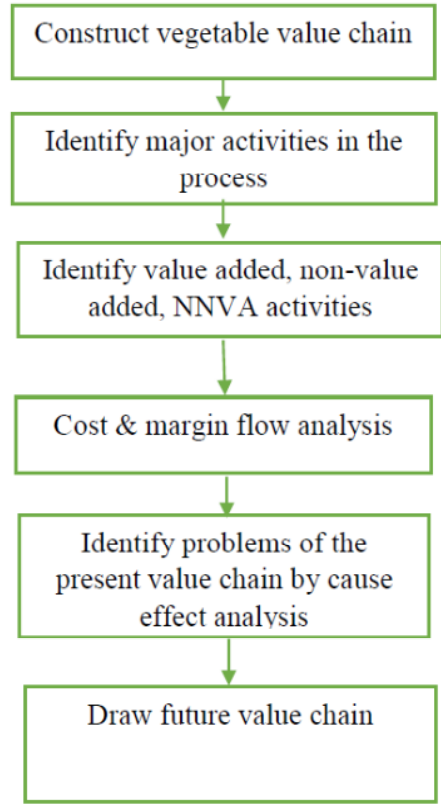

Figure 1: Analysis process of vegetable supply chain study

\section{VEGETABLE PRODUCTION SITUATION IN BANGLADESH}

Among the agro product, vegetable contributes a significant proportion. Bangladesh witnessed a revolution in vegetable production over the last decade. Proof of this is evident in the recently released FAO report. According to the report, Bangladesh has ranked third in the list of vegetables producing countries in the world. Vegetable cultivation has increased fivefold. The ministry of agricultural statistics show that the country produced a total of 13.8 million tons of vegetables in 2013-14 while the growth rate marked a steady six percent yield in each of the last three years. Currently, farmers cultivate 200 vegetable varieties. Moreover, Bangladesh now boasts of producing $90 \%$ seeds leading to that surprising high yield.

In last year, the country's overall export revenue marked an 11.65 percent increase. Exports of vegetables and fruits jumped to 60 percent,while earnings raised by $34 \%$ percent. Years back, Bangladesh had to import potato from 20 countries in the past. Last year, 2013 it exported 25 thousand tons of potato only to Russia.Moreover, in the FAO report, Bangladesh leads the world 
in terms of expansion of cultivable lands. In the last years, the country saw a five per cent increase in arable lands. The fivefold increase of vegetable production since independence has given birth to the hope of achieving nutrition security. Government efforts like providing highquality seeds, disseminating the knowledge of latest cultivation methods, allocating fertilizers have largely contributed to the success.

\section{Present value chain map}

The value chain map shows the movement of the vegetable product among the supply chain and identifies the actors and their activities. In present supply chain, illustrates in the figure 2 identify the major channel of the vegetable supply chain in Bangladesh. The value chain starts from the producer and end at consumers. From producer to consumer,

product follows a lengthy market channel.Different market actors known as market intermediaries or stakeholder involve in this value chain. Other market intermediaries are the local wholesaler, divisional wholesaler, the regional wholesaler, and retailer.

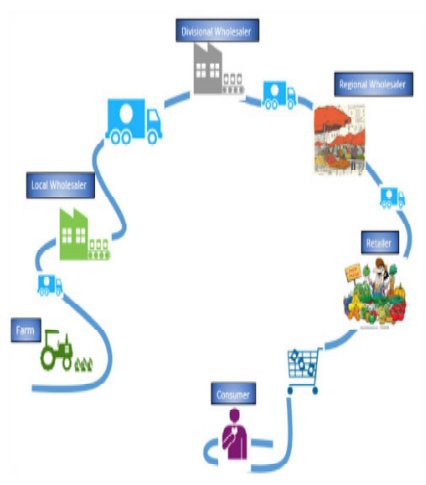

Figure 2: Vegetable value chain in Bangladesh

- Farmer: Farmers are the producer of the vegetable. They produce different types of vegetable and bring their product to sell in their local market.The amount and types of vegetables differ from season to season. The farmer sells $90 \%$ of their product to the local wholesaler and the remaining $10 \%$ in the local retail market $\square$

- Local wholesaler:Local wholesaler purchases their product from the farmer. Basically, they fixed the price paid to the farmer. They deal with the divisional wholesaler.Local wholesaler sends their product lot to the different division, according to the market demand and market price. They also sell their product to the local market, but a little amount. They make a market margin of $15 \%$ to $25 \%$.

- Divisional wholesaler: Divisional wholesaler collects their product from local wholesalers. They deal with a large amount of vegetable. Actually, they act like a divisional distributor. They sell their product to the regional wholesaler. They serve as a fixed commission agent. They also sell their product to the local retailer. They make a margin about $5 \%$ to $10 \%$.

- Regional wholesaler: Regional wholesaler collect product from the divisional wholesaler. Sometimes they collect their product from local wholesalers. They make a market margin about $5 \%$ to $10 \%$.

- Retailer: Retailer is an end connector to market. They are directly linked to the consumer. They purchase their product from the wholesaler and sell to the consumer and make a market margin about $5 \%$ to $15 \%$. 


\section{MARKet Channel OF Vegetable FroM JESSORE TO DHAKA}

Jessore is famous for its vegetable production. . In the year 2015, about 14105 hector land cultivates only for vegetable in Jessore area. (Source: Agriculture Extend Division, Jessore).Farmers bring their product to local wholesale market. The major vegetable wholesale market in Jessore area is, CuramonKathi Bazar, Baro Bazar, Satmail, Cougacha Bazar, Jhikorghacha, Kajurabazaar etc. The wholesaler from those markets purchases their product from the local farmer and sells these vegetables to the other divisional wholesaler.

They send their product to Dhaka about $60 \%$, Khulna about $20 \%$, Barisal about $10 \%$, Pirojpur about 3\%, Gopalgonj about 3\%, Bagerhat about 2\% and other regions about $2 \%$.Sometimes they directly sell their product to other wholesalers, and sometimes they used other wholesalers to sell their product and give a market percentage after they sell. Regional wholesale market like Karwan Bazar, Mirpur, Jatrabari market collects their product from the divisional wholesaler or sometimes local wholesaler. The divisional wholesaler also sells their product to other small wholesalers and retailer. The retailer in Dhaka city collects product from the regional wholesaler. The retailer sells their product to consumers.

\section{ACTIVITIES INVOLVED IN THE PRESENT VALUE CHAIN}

Value stream analysis is used to examine vegetable supply chain. In this analysis, activities are divided into three types. These are value added activities, non-value added activities and necessary non-value added activities. Value added activities are those activities; customers are willing to pay for it. The consumer only pays for value added activities like production, cleaning, processing, and packaging for maintaining good quality. These activities are important and essential for every value chain. Non-value added activities are intermediaries holding and stocking for a long time, unnecessary processing like using chemicals to keep vegetable, fresh and green for a long time, intermediate loading and unloading etc. This nonvalue added activities are done by various intermediaries like the local wholesaler, divisional wholesaler, the regional wholesaler, retailer, etc. Holding vegetable usually adds no value to the product but its increase handling cost, quality cost, etc. Only value added activities are directly involved with production activities. In vegetable supply chain value added activities are limited.

In the supply chain, there is another type of activity which is not related to production or value added activities, but these types of non-value added activities are unavoidable. These types of work are known as necessary non-value added activities. Necessary non-value added activities are transportation, receiving, measuring weight by various intermediaries. The analysis takes place between every step in the value chain and the major activities like value added, non-value added and necessary non-value added activities are identified.

\section{Activities between farmer and local wholesaler Value adding process:}

1. Collecting vegetable

2. Cleaning

\section{Non value adding process:}

1. Holding

2. Packaging

3. Loading and unloading 
Necessary non-value adding activities:

1. Transportation to local market

Activities between local wholesalers to divisional wholesaler Non value adding process:

1. Loading Truck

2. Unloading

3. Intermediate holding

Necessary non-value adding activities:

1. Transportation

Activities between Divisional wholesalers to Regional wholesale market

Non value adding process:

1. Loading

2. Unloading

3. Intermediate Holding

Necessary non-value adding activities:

1. Transportation

Activities between Regional wholesaler to retailer/supper shop:

Non value adding process:

1. Loading

2. Unloading

3. Intermediate holding

Necessary non-value adding activities:

1. Transportation

Activities between Retailers to customer:

Non value adding process:

1. Holding at Retailer

2. Unloading

Necessary non-value adding activities:

1. Transportation

2. Cleaning

Total number of activities between farmers towards customers: 22

Numbers of value adding activities: 2

Numbers of non-value adding activities: 14

Numbers of necessary non-value adding activities: 6

Total 22 major activities found in this vegetable value chain, in which numbers of value adding activities are 2. These value adding activities are reaping vegetable from the field and cleaning. These value adding activities are done by the farmer. Value adding activities consume about $9 \%$ of the whole activities (Figure 3). 
The number of non-value adding activities in this supply chain is 14. Mainly these non-value adding activities are intermediate holding, loading and unloading trucks in different stage state above by different intermediaries. This non-value adding activities consume a maximum percentage of total work and it is about 64\% (Figure.3). These activities increase the cost of the product and create a high price for the ultimate consumer. The number of necessary non-value adding activities is 6 . They are related to transportation at the different level and necessary nonvalue adding activities consume about $27 \%$ of the total amount (Figure 3 ).

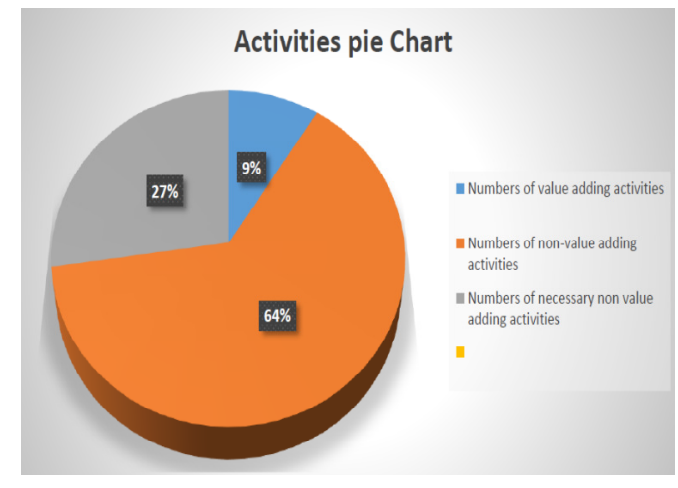

Figure 3: Activities pie chart

\section{COST AND PRICE MOVEMENT IN VALUE CHAIN}

At each and every step of a supply chain, the cost is added to the product. So the price is increased consequently. As it is an inefficient and long chain of market intermediary cause's price increase dramatically from farmer to consumer. Sometimes price is two to three times of farmer's selling price. The study investigates the price at every level of this vegetable value chain and the possible causes related to the increase of price. The existing vegetable marketing system consists of a farmer, local wholesaler, divisional wholesaler, regional wholesaler, retailer and consumer.

Price is negotiated between the farmer and the local wholesaler. Product and cost flow start from the farmer. The farmer is the ultimate producer of vegetable. He invests his capital, land, and labor to produce vegetable. So he added value and price in the vegetable. Cost involve in his activities. The farmer passes his vegetable to a local wholesaler at a cost; negotiate between him and the local wholesaler. Local wholesaler passes it to divisional wholesalers at a price higher than his cost. He takes margin from his exchange. The divisional wholesaler sells it to the regional wholesaler. The regional wholesaler passes it to the retailer and retailer sells it to the consumer. Due to the variation of time, cost, amount and activities involve in the process, this price addition may be different. The study considers the buying price from the farmer of a group of vegetable and this price is taken on $6^{\text {th }}$ August 2015 and the selling price of the same vegetable at the retail market of Dhaka is taken on $7^{\text {th }}$ August 2015. We found that the selling price in the retail market is twice than that of the selling price of the farmer. For example, buying price of Eggplants on $6^{\text {th }}$ August 2015 was 30 to 40 Taka per kg at Curamonkathi Bazar, Jessore. The selling price of eggplants on $7^{\text {th }}$ August 2015 in the retail markets in Dhaka was 70 to 80 Taka per $\mathrm{kg}$. Price spread for per kg eggplants is about 40 Taka

Figure 4 represents the percentage of price increase of various vegetables. The maximum price increase was about $150 \%$ to $190 \%$ for Ribbed gourd, and the minimum price increase was about 
$85 \%$ for Okra.The study found that the price margin of bitter gourd for the farmer was about $53 \%$, local wholesaler $21 \%$, divisional wholesaler $10 \%$, regional wholesaler $7 \%$, and retailer was about $9 \%$. The profit margin varies from product to product. These percentages of the margin of various vegetables among different stakeholder are represented in a bar chart (figure 5). The maximum margin is shared by local wholesaler and retailer after producer.

Local wholesaler receives maximum margin percentage because they bear the cost of transportation and packaging. They have also their own cost, related to rent, labor fee, market fee, Transportation cost, etc.

As retailer sells only a small amount of vegetable they added maximum margin after local wholesaler. Other market actors share relatively same market margin and their cost was relatively same.

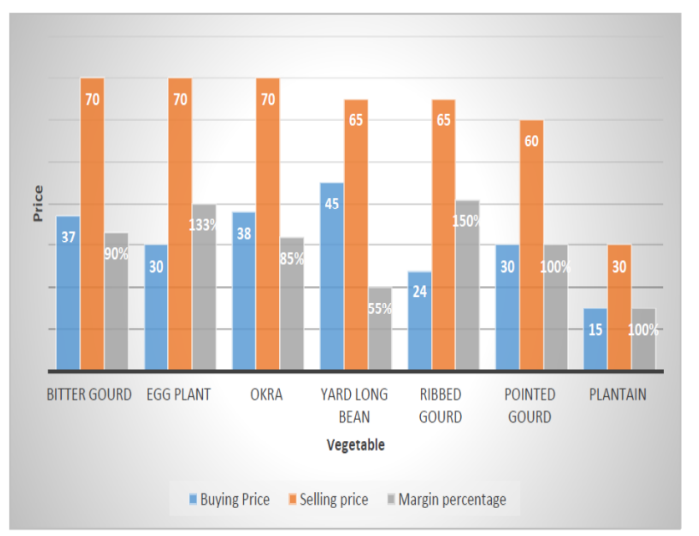

Figure 4: Purchasing and selling price and margin of various vegetables on $7^{\text {th }}$ August 23, 2015

We have analyzed this value chain and tried to identify the major cause of price hike. The causeeffect analysis is introduced to identify the price hike (Figure 6). The major causes are divided into man related cause, process related cause, material related causes, transportation- related causes, and environment related cause.

On a man related price hike, the study found that vegetable supply chain is a long supply chain, many stakeholders and labor involve in the channel.

Every stakeholder shares margin for their involvement and activities. So the ultimate price is raised for so many market intermediaries. As the labor cost rises high, every labor needs to pay 300 to 400 Taka per day, this is also a cause of price hike of vegetable. Numerous types of transportation are needed in the vegetable supply chain. For the transportation between two markets actor, loading and unloading truck is needed.

This unnecessary loading and unloading need extra labor and extra cost. Intermediate holding also considers extra cost as holding cost, processing costs, and labor cost. These processes related causes are responsible for the price hike of vegetable. Transportation is very important in the vegetable value chain. Various types of transportation are required to bring the vegetable from the farmer to the consumer. So it takes a huge amount of cost on the total product cost. Transportation related causes are the traffic jam, long distance needs extra payment, additional duty cost of the bridge and the ferry, unnecessary and unlawful money collection in 
transportation, etc. On the other hand, in Jessore, CNG gas station is not available; as a result, the vehicle need to use Diesel or Petrol as a fuel and this incurs higher costs than CNG. As a result, it's creating a huge amount of extra cost on the final product .Material related price hike causes are packaging cost, quality cost, and disposal cost.

To ensure good quality vegetable, market actor needs extra care on packaging, transportation, handling etc. which create the additional payment. Market syndicate and intermediate domination are one of the major causes of the price hike. In every market, there exist market syndicate and government have no control over them. So they create artificial demand over the market and raise the price every time without any causes. They take maximum margin as their profit from the market. They dominate the farmer and the customer. They don't share the actual market information to the farmer and the customer for their profit.

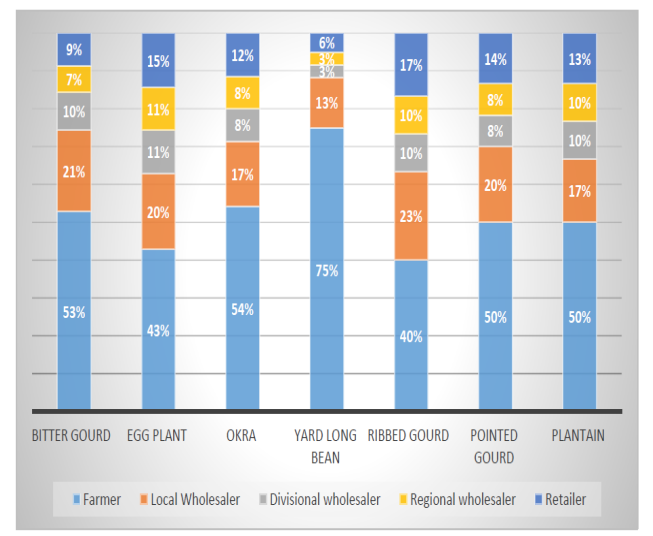

Figure 5: Percentage of market margin of various vegetables among the market intermediaries

\section{Problems of EXISTING Vegetable SUPPly Chain}

By analyzing the existing vegetable supply chain, several problems have been identified. The problems are explained below:Long supply chain

Supply chain always involved to improve the product flow and minimize the cost. The intermediaries play a vital role to make a proper connection between the producer and consumers, but too much involvement of intermediaries in the supply chain can cause the unequal price margin for both the producer and the consumers and also creates a long awaited supply chain which is not appropriate for the perishable product like vegetables. Because the value or quality of vegetable will decrease rapidly once they are harvested and will keep decaying when being delivered. The revenue of the supplier will depend on the condition of the product when they are received. Thus, the timely production and delivery of perishable foods significantly affect the supplier's revenue. So a simply understood and properly structured supply chain is much needed for a successful vegetable production flow. Many intermediaries from farmer to customer

Intermediaries make a connection between the producer and the consumer. They should be very honest and friendly for a better supply chain. But in Bangladesh there are many intermediaries involvements in one food supply chain and they are cutting off a major portion of the consumers' price as profit and also they throw different types of syndicate towards the poor farmers. Local 
wholesaler, divisional wholesaler, regional wholesaler, retailer are the different kinds of intermediaries in the vegetable production flow

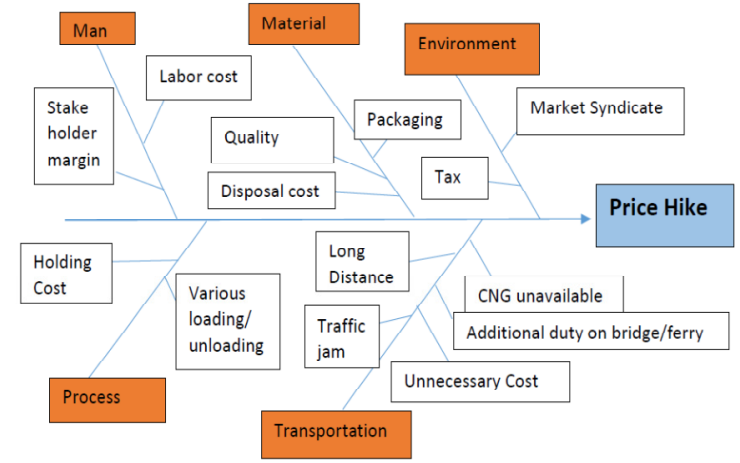

Figure 6: Cause effect diagram for price hike

Non-value added activities in the supply chain

The more there are a number of intermediaries the more there is a number of non-value added activities which are of no use rather increases the price of the product. The huge numbers of intermediaries added the extra cost. These are inventory cost, labor cost, packaging cost at the different stages of the stocking and loading- unloading options in the local market and thus increases the total cost of the produce.

Intermediaries syndicate

In Bangladesh, many intermediary wholesalers manage the vegetable flow from producer to customer. Local wholesaler, divisional wholesaler, regional wholesaler, and retailer are the different types of intermediaries and they form the intermediary syndicate for the producer in different stages of the vegetable supply flow. In which producer bound to pay otherwise he will not be able to sell his product to the market.

Seasonal climate problem and natural disaster

Bangladesh has a unique climate year for vegetable production. The year is divided into two distinct seasons: Rabi (winter from October to November) and Kharif (hot humid season from April to October). Rabi season has a relatively low temperature, humidity, and rainfall so it is suitable for most of the vegetable crops. But the irrigation problem with this season hinders production. At the peak harvest time,the farmers do not even recoup production costs by selling their product. During the Kharif season, only a few vegetables can be successfully grown.The high temperatures and high rainfall of the Kharif season are not conducive for most other vegetables.

As a result, there is always a serious scarcity of vegetables during the Kharif season. The price of vegetables at that time is very high; so much so that vegetable prices often exceed the regular price. To improve vegetable production and supply, we should develop varieties suitable for growing in the adverse weather condition of the Kharif season and drought resistant varieties of the Rabi season. 
Unstable demand and supply

During the peak season, a market glut causes the producers to sell their product at a throw-away price. Under this situation, farmers lose their interest in growing vegetables on their own. Inversely, in Kharif season there is always a scarcity of vegetables and the price of vegetable at that time is very high. To improve this vegetable production, supply and demand, we should develop a variety of options suitable for growing in the adverse weather conditions of the Kharif season and drought resistant varieties of the peak Rabi season.

\section{Lack of Government control over market}

The vegetable distribution in Bangladesh is mostly terminated by the local wholesaler and stakeholders. Government involvement in vegetable marketing is minimal and it is almost zero. The price is determined by open bargaining of buyer attending the market, thus the poor farmers are bound to sell their produce at that insufficient price. But if the government established a proper price policy for the vegetable producer then this price difference can be solved immediately from the market. The government should regularly check the market to control intermediary syndicate. The government should take action against hoarders and market manipulators to control country's marketing system.

Farmers are bound to sell to a local wholesaler syndicate

Due to market information available to producers and also a lack of accessibility to a high value market, producers are always in mess thinking about whom to sell their product in time and as a result, they are often bound to sell their product to local wholesaler syndicate at a very cheap price.

Creation of an artificial demand

Sometimes the cunning local wholesaler makes an artificial demand among the market only to cheat the producers.

They make a fake sort of demand. As a result of that demand, producers then sell their whole bunch of product to the wholesaler at a very reasonable price thinking that this is their profit. But actually they are in a huge loss because the wholesaler then sells this product at a very much higher price in town and city market.

Unequal profit margin system

Vegetable production, marketing depends on many intermediaries because of the lack of proper infrastructure and results huge delivery cost and wastage. The price of vegetable increases with the number of intermediaries and price is less if there are fewer intermediaries. Thus, the price of vegetables at a different market of Dhaka becomes almost multiple times higher than that in rural areas. This unequal profit margin brought clumsiness among the producers and deprived them.

A Poor transportation system causes extra cost

As a reason of socioeconomic conditions of Bangladesh, most of the vegetable market is located mainly in the towns and cities. The transportation system in rural areas is very poor, so the marketing of growing vegetables from the rural areas to urban towns is expensive. As a result, growers have to pay extra money for the transportation.

Inadequate knowledge and skills of producers in using modern techniques

A great cultivation of vegetable production requires more care than the cultivation of field crops. 
But in Bangladesh most vegetable growers are women and unfortunately, they are not aware of modern cultural practices. They follow traditional methods of cultivation and grow low crop yields. Improving cultural methods of vegetable production can increase the yields significantly.

Lack of knowledge in identifying appropriate inputs such as seeds and fertilizer

Bangladesh imports many exotic vegetable seeds almost all of which are hybrids and therefore, the import of this seed is recurrent processed. Our farmer's lack of education and without any suitability study, they raised crops from that seed which results in partial or total failure. Though Bangladesh is a nature farming agricultural country, more famous with the use of different organic materials such as cow dung, farmyard manure, and oil cakes but farmers started using Agrichemicals in crop production for the quality of the crop.

Lack of access to high value market

The vegetable producers of Bangladesh are not getting high food price due to deficient access to high-value market information and undeveloped infrastructure. They do not know anything about high -value market due to their lack of knowledge about the present and updated trend in business, thus the wholesalers took this advantage and buy their product at a low price.

Weak marketing system and lack of market information available to producers

A weak marketing system can hinder agriculture development which upsets to country development. Marketing system mainly depends on the efficiency of the transportation of the vegetables from producers to consumers. In Bangladesh, the transportation system is so poor in rural areas. It leads to losses as vegetable deteriorates quickly over time.

The weak marketing system is also a result of lack of market information of the producers due to their lack of proper education and knowledge towards the new era.

\section{Proposed value chain}

Agriculture value chain is a way to move the vegetable product from producer to consumer. The analysis presents vegetable value chain and identified the various problem related to vegetable production and marketing. Current value chain involves several intermediaries in the process. As a result, their involvement and activities raised the vegetable cost at the end market. Consumers need to pay the excessive price and producer receive very low price from their production. Maximum margin goes to intermediaries, stock. Naturally, the producer and customer want to minimize the number of intermediaries, marketing step and their activities as much as possible. So that the farmer will earn more and consumer will pay less. By analyzing the present value chain, we proposed a future value chain which will help both the farmer and the customer. Our proposed value chain consists of 5 steps instead of 7 steps in the current value chain.

Our proposed future value chain consists of a farmer, farmer's collection center, regional/divisional wholesaler, retailer and consumer. In our future value chain, we remove local and divisional wholesaler and add farmer's collection center. Our main focus is to involve farmers in their vegetable marketing. The proposed value chain is illustrated in figure 7. A farmer's cooperative can be established in each and every village. The organization will organize, and manage by the farmers. This farmers' cooperative will build a collection center in their production area. This collection center will also be managed by farmers themselves. The functions of these cooperative are the collection of member's vegetables, contact with regional wholesaler and retailer, managing credit service, and managing information. The collection center 
will involve in activities like the collection of market information, the collection of products, price determination, proper distribution, transportation, storage and other marketing activities. As the collection center form by the farmers themselves, it will help the farmer to get the fair price. They can negotiate prices with wholesaler and retailer. This value chain will be more efficient if they sell their product to the retailer directly. The cooperative must have some strategic planning and business policy to manage their business. The strategic planning must ensure their fundamental goal to achieve a fair price for their product. The collection center will receive a percentage about 2 to $5 \%$ on their total sell to bear their expenses of the cooperative. . Bruynis [8], for instance, executed an empirical survey with 52 American marketing cooperatives and distinguished eight keys to success, understood in terms of longevity, business growth, profitability and member's satisfaction. Such factors as implementation of a management training process, employing an experienced full-time general manager, regularly distributing accurate financial statement among the management team, using marketing agreements to secure business volume commitments from the members, and. utilizing human resource appeared to be significant for the researched organizations achieving success. Regarding the implementation of their main task, i.e. , organizing joint sales of the output produced by an individual member farmer. Farmer's collection center acts as an intermediate market organization that coordinates the exchange of vegetable between the farmers and retailer. In our future model farmer's collection center passes their product to regional wholesaler or retailer. And retailer will sell the product to the consumer. Due to reduction of many intermediaries, product cost will be minimized. The most efficient value chain will be established if farmers collection center confirms their business directly with the retailer instead of the wholesaler. As a result, it will reduce the supply chain and supply chain cost. So that the farmer will get the fair and attractive price and consumer will get the product at a lower cost.

\section{COST ANALYSIS OF PROPOSED VALUE CHAIN}

We proposed a value chain avoiding local and divisional wholesaler and we replaced them by farmer's collection center. For our new chain, we analysis the future cost if we consider the same data of vegetable price collected on $7^{\text {th }}$ August 2015. We proposed that collection center will act like intermediaries in this value chain, but this collection center will govern and managed by the farmers. For the expenses of collection center, we recommended 2-5\% margin for farmers' cooperative. We assume all the data will be same. So if we consider bitter gourd for our future price analysis, we found that farmers will sell their bitter gourd to the collection center at a price about 37 Taka per kg.If we consider the maximum percentage of collection center, then the margin will be 2 Taka per $\mathrm{kg}$. The Collection center sells the product to a regional wholesaler or direct retailer. If the collection center will sell their product to regional 


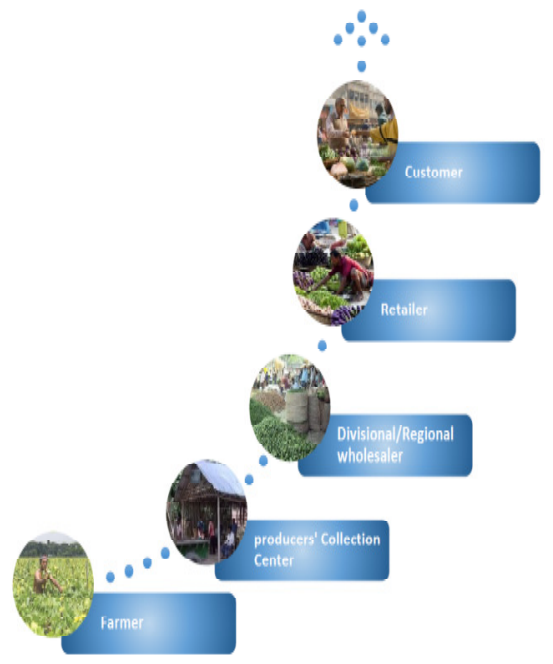

Figure 7: Proposed future value chain

wholesaler and regional wholesaler passes the product to the retailer, then the total price of per $\mathrm{kg}$ bitter gourd will be 60 Taka. And if the collection center will sell the product directly to retailer then the price of per kg bitter gourd will be 45-50 Taka. By comparing these price with present value chain, price will be reduced 10 Taka to 25 Taka. Thus saving money, farmers can share a fair price of their product and consumer will get the product at a lower price. A comparison of the price of the product between present value chain and future value chain is represented in the bar chart.(figure 8)

\section{CAUSeS OF PRICE REDUCTION IN PROPOSED VAlue Chain}

From the above analysis, it is found that vegetable cost will be reduced in the future value chain. There are various causes behind this reduction. Present supply chain contains more intermediaries like the farmer, local wholesaler, divisional and regional wholesaler, retailer and the customer.

But in the recommended value chain local and divisional wholesaler will be substituted by farmers' cooperative collection center. It is a farmer's organization and it ensures their fair price. From the present value chain, we avoid local wholesaler and divisional wholesaler and their activities include value added, non-value added and necessary non-value added activities. So avoiding their non-value added activities, the percentages of non-value adding activities will be reduced and value- added activities will be increased in percentage. In present supply chain percentages of non-value adding activities is $64 \%$. But avoiding local and divisional wholesaler activities the percentage of non-value adding activities will be $52 \%$. The cost related to local wholesalers and divisional wholesaler will be reduced. The cost related to present value chain is represented in figure 9 . 


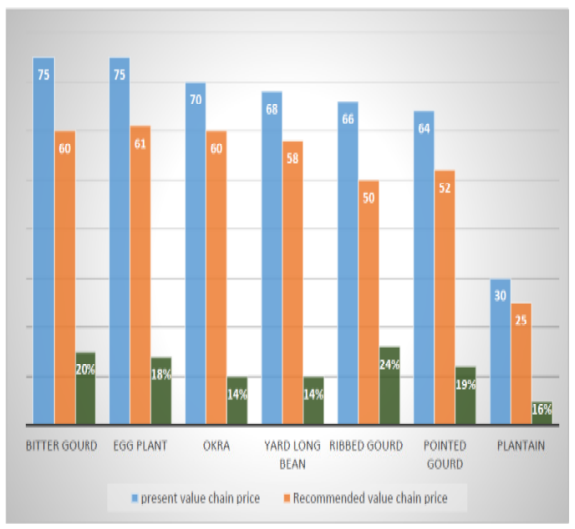

Figure 8: Comparison between present and future value chain price

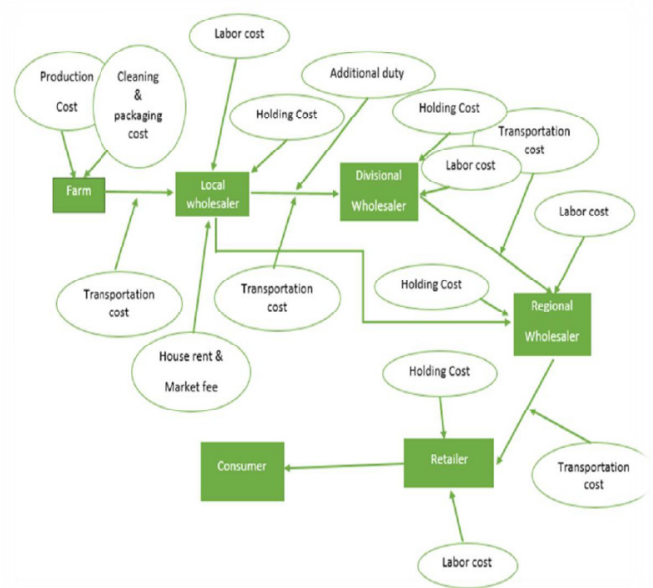

Figure 9 : Cost related to present vegetable value chain

In the recommended value chain local wholesaler and divisional wholesaler are substituted by the farmer's collection center. So the cost related to the local and the divisional wholesaler like holding cost, labor cost, market fee, market rent, transportation cost will be reduced from the ultimate product price. The cost related to recommended value chain is represented in figure 10 .

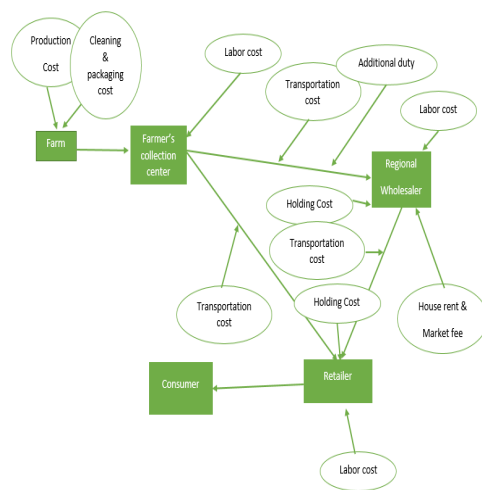

Figure10: Cost related to the recommended value chain 
In the recommended value chain, farmers' cost is same as present value chain, but the farmer needs very low cost or sometimes don't need cost for transportation to bring their product to collection center because the collection center will build in the production area. At the collection center only labor cost is needed, holding cost is not required for collection center. Manager of farmer's collection center directly contact with regional wholesaler or retailer. To bring the product from the collection center to regional wholesaler, transportation cost and additional duty on the bridge of the ferry is required. Cost related to regional wholesaler is holding cost, labor cost, house rent and market fee. Cost related to retailer is labor cost, holding cost. So by comparing the recommended value chain with present value chain, various cost and activities related to local and divisional wholesaler will be reduced so the ultimate price of the final product will be reduced about $10 \%$ to $30 \%$.This will help the farmer to get a fair price and increase their revenue.

\section{E-COMMERCE BASED FUTURE VALUE CHAIN}

To provide easier communication between the producer and the other market actor like a retailer, we proposed an e-commerce based value chain. A common online marketplace can be built where the producer and the other market actor easily access from their mobile or computer. A common website can be designed where the farmers can advertise their product. On the website, the farmer will provide product photo, information and contact details. Wholesaler and retailer will browse that site and check the product and contact with the farmer.

After negotiation, the farmer will send the product to the appropriate customer with the appropriate amount. This website of apps can be made by a third party.

They only make a common place for communication between the farmer and the intermediary customer, but not involve in the business. The following figure shows the whole process

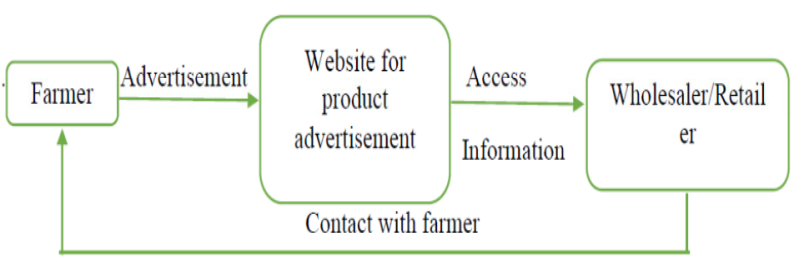

Figure11: Flow chart of e-commerce based value chain

\section{CONCLUSION}

In this paper, value chain analysis in terms of its theoretical background and its application to vegetable value chain in Bangladesh is introduced. Vegetable value chain studies provided valuable insights into the supply chain structure, market actors, intermediary's activities, their operations, value adding, price and profit margin movement of the existing value chain.The vegetable supply chain has its particular structure and special demand. The study is mainly focused on the investigation of the product flow from the farmer through various marketing intermediaries to the consumers. This study primarily identifies the market intermediaries between the farmer and the consumer and their activities in the value chain. We categorized their activities as value added activities, non-value added activities, and necessary non-value added 
activities. We identified a huge portion about $64 \%$ of non-value added activities, which is redundant. This redundant activity raises the prices of the product. We studied the cost and price movement along the value chain and found that consumer price of vegetable is almost double of producer price margin. Different market intermediaries share profit margin with the farmer. Analyzing this vegetable value chain of the targeted area, we identify the major problem along the existing vegetable value chain. Producer and consumer are not getting the full benefit of vegetable price due to deficient access to market information and undeveloped infrastructure. There are many intermediaries, inferior communication, and transport condition, inadequate financial and information service also contribute unequal profit margin distribution and a high price of the vegetable. Government involvement, coordination and monitoring on price fluctuation in the existing value chain are limited. Backward pricing system and market syndicate cause losses for the producer. Understanding the value chain, problem, opportunities, and analysis of global value chain, we recommended a new value chain. In ours recommended future value chain, we avoid some redundant market intermediaries and their activities to make the supply chain more efficient and competitive. Our recommended value chain ensures farmers a fair price by direct marketing in a high value market as well as consumer lowest consuming price as much as possible. Effective management and monitoring system of Government reduce the gap between the farmer's price and consumer price. By implementing our proposed value chain, it is possible to change the vegetable pricing system and vegetable supply chain in the future.

After Analysis, along with our proposed value chain, we have recommended some guideline towards the improvement of the vegetable supply chain in Bangladesh that are mentioned below.

- Create a business link between the farmer's collection center and a high value market for direct selling.

- The government should monitor market regularly and take action against market syndicate.

- The government should introduce the pricing policy for the different season for the different perishable agro product.

- Transportation system and facilities should be developed and the government should take necessary steps to avoid additional cost during transportation.

- Information and communication system should be developed among the producer.

- Interest -free agricultural loan and crop insurance should be provided for farmers.

\section{REFERENCES}

1. Chopra, S., Meindel,P.,\& Karla.(2013). Supply Chain Management, $5^{\text {th }}$ eds, Pearson education Inc.

2. Das, R., \& Hanaoka, S. (2010). Perishable Food supply chain constraints in Bangladesh

3. Hawkes, C.,\& Ruel, M. (2011).Leveraging agriculture for improving nutrition and health. International food policy research conference, Washington DC.

4. Kaplinsky,R.,\&Morris,M.(2001). A Manual for value chain research,wwww.ids.ac.uk/ids /global/.

5. Sanogo, I. (2010).Market analysis tool-how to conduct a food commodity value chain analysis. World Food Program and VAM Food Security Analysis.

6. Lusine,H., Alfons, G.J.M., Jack, G.A.J.,\& Olafvan, K.(2007).Performance measurement in agrifood supply chains: a case study. Supply Chain Management: An International Journal, 12 (4); $304-315$.

7. Taylor,D.H. (2006). Strategic considerations in the development of lean agri-food Supply chain: study of the UK pork sector, Supply Chain Management: An International Journal, Vol.11 
Iss:3,pp.271-280

8. Bruynis, C., Hahn, D.E., \& Taylor, W.J. (1997). Critical success factors for emerging agricultural marketing cooperatives, American Cooperation, 50-54 [An annual publication of the National Council of Farmer Cooperatives, Washington, DC.

9. FAO (2014). Statistical Yearbook of Food and Agriculture Organization of United Nations.

10. Gibbon, P., \& Ponte,S.( 2005). Trading Down: Africa, Value Chains, and the Global Economy. Temple University Press.

11. Bangladesh Bureau of Statistics (2015) Agricultural Census 2014.

\section{Authors}

\section{Rubayet Karim (Bangladesh)}

Assistant Professor, Jessore University of Science and Technology, Jessore,Bangladesh., Rubayet Karim joined Jessore University of Science and Technology, in 2010 and has been the Asst.Professor of Department of Industrial and Production Engineering since 2014. His research interests are value chains, supply chains and operations management.

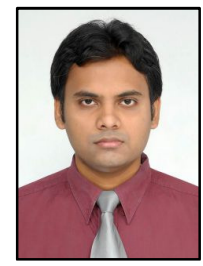

\section{Jony Biswas(Bangladesh)}

Graduate, Dept. of Industrial and Production Engineering,Jessore University of Science and Technology, Jessore,Bangladesh. After graduation, Jony Biswas is now working as a Industrial engineer in a textile manufacturing company in Bangladesh.

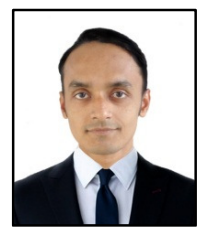

